\title{
ВПЛИВ ПРОФЕСІЙНОЇ МОТИВАЦІЇ НА ВИНИКНЕННЯ ВНУТРІШНЬООСОБИСТІСНОГО КОНФЛІКТУ В СТУДЕНТІВ ПЕРШОГО РОКУ НАВЧАННЯ
}

УДК: 378.015.3: 159.964.21

\section{Шульга Галина Борисівна}

Кандидат педагогічних наук, доцент кафедри психології та соичальної роботи Вінницького державного педагогічного університету імені Михайла Коияюбинського, м. Вінниия (Україна)

\section{Коломієць Леся Іаорівна}

Кандидат педагогічних наук, старший викладач кафедри психологї та соціальної роботи Вінницького державного педагогічного університету імені Михайла Кочююинського, м. Вінниия (Україна)

\begin{abstract}
Анотація. $\quad$ с статті представлені основні результати теоретичного аналізу й емпіричного дослідження психологічних особливостей впливу професійної мотивації на виникнення внутрішньоособистісного конфлікту у студентів першого року навчання. На основі кількісного $і$ якісного аналізу емпіричних даних з'ясовано особливості прояву професійної мотивації та ї̈ значення для навчальної діяльності, проаналізовано мотиви учбової діяльності, мотиваційно-потребові установки, мотивація досягнень як чинників, щуо впливають на виникнення внутрішньоособистісного конфлікту у студентів першого року навчання. Представлено результати кореляційного аналізу між рівнем внутрішньої конфліктності $i$ професійною мотивацією, мотивами досягнення успіху; між рівнем тривожності і мотивацією досягнення; між рівнем емоційної напруги і професійною мотивацією. Враховуючи висновки емпіричного дослідження, визначено перспективу подальших аспектів дослідження даної проблеми.
\end{abstract}

Ключові слова: мотивачія, професійна мотиваџія, професійний розвиток особистості, внутрішньоособистісний конфлікт, мотиви досягнення.

Постановка проблеми у загальному вигляді та її зв'язок із важливими науковими чи практичними завданнями. Сучасне суспільство має потребу в кваліфікованих спеціалістах, особливо в педагогах. У становленні майбутнього спеціаліста важливе місце зай- 
має професійна мотивація. Вона виступає в ролі внутрішнього фактору, який сприяє розвитку професіоналізму особистості. На жаль, не всі студенти, особливо на ранніх етапах навчання, здатні усвідомити значущість своєї майбутньої професійної діяльності. Водночас ефективність будь-якої діяльності залежить від міри вираження професійних мотивів. Усвідомленість і сформованість професійних мотивів буде сприяти активності студентів у навчальній діяльності, а у подальшому - у майбутній професійній діяльності. Але значна кількість студентів у процесі навчання у вищому навчальному закладі керується мотивами, які не мають прямого відношення ні до процесу навчання, ні до професійної підготовки.

Проблема професійної мотивації у майбутніх спеціалістів набуває особливого значення через те, що, зважаючи на опитування, студенти вже на першому курсі втрачають інтерес до навчання і впевнені, що не будуть працювати за обраним фахом. Знання особливостей мотивів, які спонукали їх до вибору професії, дозволить зробити процес первинної професіоналізації більш продуктивним і ефективним, а також знизити рівень негативних емоційних переживань, які можуть виникати у випадку невдалого професійного самовизначення.

Аналіз останніх досліджень і публікацій, в яких започатковано розв'язання даної проблеми і на які спирається автор. Сучасні психологічні дослідження ситуації про- фесійного становлення в період студентства вказують на складність дорослішання і підкреслюють неминуче переживання внутрішньої конфліктності, емоційного дискомфорту у зв'язку з неоднозначністю освоєння майбутньої професії. Ефективність входження молоді в професійний світ залежить від міри задоволеності обраною професією, тобто від рівня сформованості професійних мотивів.

Аналіз проблеми професійної мотивації здійснювався Т. Гордєєвою, Л. Грень, С. Срохіним, С. Занюком, Л. Мітіною, І. Нікітіною, Ю. Нікітіним та ін. Мотиви вибору професії вивчали Б. Барчі, С. Кусакіна, Н. Спірідонов та ін. Питанням формування мотивів навчально-пізнавальної діяльності студентів вищих навчальних закладів, розвитку їх мотиваційної сфери присвячені роботи Р. Боркієвської, Н. Бондаренко, I. Зайцевої, Н. Клименко, С. Ames, J. Archer, A. Elliot, A. Kaplan, M. Maehr та ін. Проблемами формування професійно важливих якостей майбутніх фахівців під час професійної підготовки займалися Л. Долинська, Л. Журавльова, Ю. Поваренков, Н. Шевченко та ін.

Проблематика внутрішньоособистісного конфлікту у зв'язку із професійним становленням розкрита у працях Н. Волянюк, Н. Герасімова, Е. Зеєра, С. Кузікова, Г. Ложкіна, Н. Пов'якель, Н. Чепелєвої та ін.

Виділення невирішених раніше частин загальної проблеми, яким присвячується стаття. Нині є потреба в дослідженні й з'я- 
суванні особливостей кожного етапу розвитку і становлення професійної мотивації студентів. Також залишається недостатньо вивченою проблема професійної мотивації як детермінанти виникнення внутрішньоособистісного конфлікту студентської молоді.

Мета статті - виявити особливості впливу професійної мотивації на виникнення внутрішньоособистісного конфлікту в студентів першого року навчання.

Виклад основного матеріалу дослідження 3 повним обгрунтуванням отриманих наукових результатів. Проблема професійної мотивації - однією з центральних проблем сучасної педагогічної психології, про що свідчить чимало різнопланових наукових пошуків у цьому напрямку. Вибір і прийняття професії - завжди критичний момент у розвитку особистості, оскільки він пов'язаний із вирішенням комплексу протиріч, в основі яких знаходиться опозиція між індивідуальними й соціальними потребами $[8,10]$. Невміння робити вибір або ухиляння від вибору може призвести до погіршення емоційного стану особистості, появи негативних переживань, страждань інших, втрати сенсу життя, розгортання внутрішньоособистісного конфлікту, прояву невротичних проблем. Численні психологічні, соціологічні дослідження наводять невтішну статистику щодо мотивації вступу до вищих навчальних закладів, зокрема й педагогічних. Згідно опитувань, тільки 43\% студентів мають орієнтацію на оволодіння майбу- тньою професією, решта - уже 3 першого курсу не мають бажання працювати за фахом. Одним із провідних мотивів вступу до вищого навчального закладу визначають мотив отримання диплому. Така тенденція свідчить, що студенти спрямовані не на сам процес навчання, а лише на його результат, а переважання мотиваційної готовності над професійною дає право говорити про більшу готовність респондентів навчатися у вищому навчальному закладі взагалі, ніж отримати професійну освіту за певною спеціальністю [5, с. 59]. Щодо мотивів вибору професії педагога, вихователя, то сучасні дослідники з прикрістю констатують вираження ситуативного мотиву вибору, інфантильну спрямованість навчально-професійної діяльності, недостатню усвідомленість вимог майбутньої професії та власних особистісних якостей, недостатній розвиток мотиваційних характеристик становлення комунікативних $\mathrm{i}$ організаторських умінь, легкість вступу до педагогічного вищого навчального закладу, можливість спілкування з однолітками, необхідність часу для самовизначення, наявність диплома про вищу освіту тощо.

Дослідниця В. Барчі виокремила мотивуючі причини, що змушують людину займатися тією чи іншою працею, об'єднавши їх у такі три групи: у першу групу віднесені причини, що спонукають усвідомлення необхідності приносити користь суспільству, бажання надавати допомогу іншим людям, суспільна установка на необхідність трудової діяльності; 
другу групу склали причини отримання певних матеріальних благ для себе та власної родини; третю групу становлять потреби в самоактуалізації, самовираженні, самореалізації [1, c. 64]. Отже, вибір професії - це складний, а інколи довготривалий мотиваційний процес. Аналіз мотивації вибору професії дасть змогу визначити рівень професійної мотивації особистості.

В основі професійної мотивації лежать професійні мотиви. У психолого-педагогічній літературі професійні мотиви розуміються як: внутрішні спонукання, що визначають спрямованість активності людини в професійній поведінці в цілому і орієнтацію людини на різні сторони самої професійної діяльності (А. Маркова); мотиви, які спонукають суб'єкта до удосконалення власної діяльності - iï способів, засобів, форм, методів (О. Вербицький); направленість на конкретну професійну діяльність (В. Ковальов). Професійні мотиви є одним 3 видів мотивів навчання, а їх сукупність становить професійну мотивацію навчальної діяльності. Професійна мотивація - це сукупність чинників і процесів, які, відбиваючись у свідомості, спонукають особистість до вивчення та ефективної реалізації професійної діяльності [3, с. 21].

Професійна мотивація лежить в основі прагнень і готовності особистості до здійснення певних дій, вчинків на етапі первинної професіоналізації. Усвідомлення потреби в знаннях і вміннях, які необхідні для успішної про- фесійної діяльності, спонукають до активного професійного навчання у вищому навчальному закладі, що сприяє формуванню мотиву досягнення успіху, розвиває вміння ставити цілі і досягати їх. У зарубіжних дослідженнях обгрунтована achievement goal orientation theory, що розкриває прямий зв'язок цілей, яких прагнуть досягти індивіди, певного типу поведінки, якої вони намагаються дотримуватися. Цілі визначають комплекс особистісних переконань, атрибуцій і емоційних станів, що форматують наміри поводитися певним чином і виражаються в різних способах залученості до видів діяльності, які пов'язані з досягненням цілей, і реагування на них [11, с. 263]. Більшість зарубіжних дослідників не заперечує існування двох базових цілей: ціль майстерності (mastery goal) і ціль результативності (performance goal) [11, с. 264]. Студенти, які орієнтовані на досягнення цілі майстерності, концентруються на отримання нових знань, здобуття і розвиток навичок, що призведуть до особистого й професійного розвитку. Натомість, студенти, які орієнтовані на результат, прагнуть продемонструвати свої навички й знання, отримати від інших бажане оцінювання власних компетенцій або уникнути негативних оцінок [14].

Науковець Е. Елліот запропонував перейти від дихотомії типів цілей до трихотомії, а саме: ціль майстерності, результативна ціль наближення і результативна ціль уникнення. Е. Елліот стверджував, що студенти, для яких 
характерне прагнення до цілі наближення, шукають можливості, які дозволять їм досягати успіху; студенти, які керуються ціллю уникнення, схильні шукати можливості ухилятися невдач або попередити небажаний результат $[13$, с. 167]. Водночас орієнтація на майстерність і орієнтація на наближення сприяють появі позитивних емоцій і високих оцінок. Зауважимо, що деякі дослідження виявили й негативні наслідки орієнтації студентів на цілі наближення, зокрема, низьку результативність збереження в пам'яті отриманих знань [13]. У процесі експериментальних досліджень було виявлено також ще один тип мотивації - освітнє відчудження (academic alienation goal), або ухиляння від роботи (work-avoidance goal). Такі студенти не прагнуть до отримання або демонстрації знань і навичок, а налаштовані на виконання навчальних завдань 3 мінімальним зусиллям, їх не цікавлять оцінки навчальних досягнень, думки оточення [12]. Незаперечним $\epsilon$ той факт, що студенти з яскраво вираженим прагненням до успіху, досягають у житті значно більше в порівнянні з тими, у кого така мотивація слабко виражена або відсутня зовсім.

Науковці вважають, що професійна мотивація неоднорідна й залежить від багатьох психологічних і соціологічних факторів. Л. Долинська, зокрема, пропонує виділяти в професійній мотивації домінуючі професійні мотиви, які визначають стійке, тривале, активно-дійове, позитивне ставлення особистості до оволодіння психологічними знаннями, вміннями й навичками і забезпечує майбутнім педагогічним працівникам ефективність вирішення виховних, освітніх та розвивальних завдань у майбутній професійній діяльності [2].

С. Занюк вказує на присутність особливостей мотиваційної сфери студентівпершокурсників. Дослідником було з'ясовано, що в структурі мотивації навчання студентів першого-другого курсів домінують зовнішні мотиви (соціального престижу, матеріального достатку та комунікативний мотив), а внутрішня мотивація $\epsilon$ недостатньо розвинена [4, c. 276]. Очевидно, що діагностика й корекція сформованості професійних мотивів у студентів першого року навчання дозволить поліпшити процес їхньої адаптації до нових умов, сприятиме структуруванню особистісних смислів щодо процесу здобування освіти, включенню у формат нового виду діяльності - навчально-професійної.

Процес первинної професіоналізації нерідко спричиняє у студентів появу невпевненості у власному майбутньому, негативних емоційних станів і внутрішньоособистісних конфліктів. Сучасні психологічні дослідження ситуації професійного становлення у студентський період підкреслюють неминуче переживання внутрішньої конфліктності, психологічної дезорієнтації, емоційного дискомфорту в зв'язку з неоднозначністю і складністю освоєння майбутньої професії. Крім того, невдале чи аморфне професійне самовизначення на 
початкових етапах здобування вищої освіти може ускладнити адаптацію і поглибити внутрішньоособистісний конфлікт.

Під внутрішньоособистісним конфліктом будемо розуміти такий стан особистості, який характеризується переживаннями подвійності почуттів і тривалою боротьбою мотивів, інтересів, прагнень, що відображають суперечливі зв'язки 3 соціальним середовищем i затримують ухвалення рішення [6, c. 394]. Внутрішньоособистісний конфлікт супроводжується гострими негативними переживаннями, високою емоційною напругою, сумнівами, невпевненістю щодо власних бажань і домагань, неможливістю їх реалізації. До суттєвих наслідків деструктивних внутрішніх конфліктів відноситься у першу чергу те, що вони порушують життєвий цикл особистості, успішність ії життєдіяльності, знижують ефективність професійної діяльності, працездатність, сприяють виникненню втоми, розвитку неврозів, стресу, пов'язаних з неуспішністю діяльності [6, с. 138].

Результати теоретичного аналізу досліджуваної проблеми, розуміння ії актуальності для вирішення ключових завдань етапу первинної професіоналізації, досвід викладацької діяльності у вищому навчальному закладі переконали в необхідності вивчення особливостей впливу професійної мотивації на виникнення внутрішньоособистісного конфлікту в студентів першого року навчання емпіричним шляхом. У дослідженні взяли участь 98 студе- нтів першого року навчання спеціальності «Дошкільна освіта» (середній вік вибірки 19,4 р.). Для діагностики внутрішньоособистісного конфлікту і професійної мотивації студентів використовували такі методики: шкала прояву тривожності MAS (Дж. Тейлор, адаптація Т. Немчина); методика дослідження самоставлення (В. Столін, С. Пантелеєв); тест «Вивчення мотивів учбової діяльності студентів» (модифікація А. Реана, В. Якуніна); «Орієнтаційна анкета» (Б. Басс), тест мотивації досягнення (А. Мехрабіан, модифікація М. Магомед-Емінова). Математично-статистична обробка результатів проводилася за допомогою комп'ютерної програми SPSS Statistics 17.0. Для обрахунку щільності і значущості взаємозв'язків використовувався кореляційний аналіз, який здійснювався за допомогою коефіцієнта кореляції К. Пірсона.

У дослідженнях Т. Маланьїної відстежуємо взаємозв'язок внутрішньоособистісного конфлікту з рівнем самоставлення й особистісної тривожності особистості [7]. Отримані нами емпіричні показники за шкалами «особистісна тривожність»

(MAS, Дж. Тейлор) «внутрішня конфліктність» i «самозвинувачення» (методика В. Століна, С. Пантелеєва) дозволяють нам констатувати наявність внутрішньоособистісного конфлікту в студентів-першокурсників. Результати дослідження за шкалою «особистісна тривожність» показали, що у 49\% досліджуваних переважає високий рівень особистісної тривож- 
ності, у 27\% - середній, що, в цілому, вказує на переживання студентами емоційного дискомфорту, незадоволеність собою і власним життям, конформність. Аналіз емпіричних значень за шкалою «внутрішня конфліктність» дозволяє зробити висновок, що тільки 9\% студентів демонструють ознаки негативного самоставлення, надмірного самоконтролю «Я», прагнуть до глибокої оцінки всього, що відбувається в їх внутрішньому світі, в крайніх проявах - до занадтого самокопання. Переважання середніх показників (85\%) дає змогу констатувати, що більшість студентів у звичних для себе умовах мають позитивне самоставлення, адекватно сприймають власні позитивні риси, визнають негативні. Несподівані труднощі, додаткові перешкоди, які можуть виникнути в перші місяці навчання у вищому навчальному закладі, можуть сприяти посиленню недооцінювання власних успіхів.

Переважання середніх показників за шкалою «самозвинувачення» (68\%) свідчить про те, що вибірка характеризується вибірковим ставлення до себе, спостерігається ситуативне самозвинувачення за вчинки і дії. Водночас у $21 \%$ студентів високі показники вказують на їхню схильність до самозвинувачення, зневіри у власних силах, впевненості в постійних невдачах. Установка на самозвинувачення супроводжується розвитком внутрішньої напруги, відчуттям неможливості задоволення основних особистісних потреб.

Високі показники за проаналізованими шкалами методик свідчать про наявність внутрішньоособистісного конфлікту в 26,3\% студентів першого курсу. Отримані результати дозволяють припустити, що такі здобувачі вищої освіти мають негативні переживання, які можуть бути спровоковані не лише процесом адаптації до вищого навчального закладу, а й низькою професійною мотивацією.

Результати діагностики особливостей мотивів учбової діяльності (тест «Вивчення мотивів учбової діяльності студентів») вказують на переважання в досліджуваної вибірки професійної мотивації (34,7\% студентів), мотивів творчої самореалізації (22\%), комунікативних мотивів (14,3\%). Слабко виражені навчально-пізнавальні (32,8\% студентів) і соціальні мотиви (26,3\%). Це дозволяє стверджувати, що студенти розглядають навчання у вищому навчальному закладі як перспективу досконалого оволодіння майбутньою професією. Однак, професійне становлення першокурсники пов'язують, першочергово, з можливостями творчої самореалізації; навчальнопізнавальна діяльність не визнається ними значущою. На нашу думку, це свідчить про інфантильність бажання оволодівати новими професійно важливими знаннями, закономірностями, засвоювати нові способи одержання знань.

61,2\% студентів усвідомлюють значення навчання, важливість отримання нових знань, але продуктивність їхнього включення в навчальну діяльність залежить від витрат часу 
на самостійну роботу, обсягу опанування навчального матеріалу, міри самоорганізації, успішності долання перешкод тощо. Соціальні мотиви безпосередньо не впливають на процес навчання, але незначна їх представленість у структурі мотивації першокурсників негативно позначається на формуванні соціально значущих якостей особистості майбутніх педагогів.

Виявлені низькі показники сформованості мотивів учбової діяльності дозволяють констатувати наявність у студентів нейтрального ставлення до професії, ситуативної зацікавленості питаннями професійного зростання, пасивності й безініціативності. Такі першокурсники не відчувають баланс між власними можливостями й вимогами освітнього середовища вищого навчального закладу, незадоволенні життєвою ситуацією і суб'єктивними досягненнями.

У дослідженні професійної мотивації важливим показником є спрямованість особистості, оскільки вона дає можливість зрозуміти мотиваційно-потребові установки особистості. Крім того, на думку Н. Спірідонової, спрямованість особистості репрезентує властивості особистості, які задають вектор іiї ціннісно-смислового ставлення у системі «індивід-суспільство», яке формується у процесі розвитку особистості як суб'єкта суспільних відносин [9]. За методикою Б. Басса констатуємо переважання спрямованості на справу (55\%), що свідчить про зацікавленість студен- тів у вирішенні ділових проблем, орієнтацію на співробітництво, здатність відстоювати власну думку заради досягнення спільної мети. Спрямованість на спілкування характеризує 32,6\% першокурсників, для яких значущою $є$ не лише навчальна діяльність, але й підтримка емоційних стосунків 3 одногрупниками, зорієнтованість на соціальне схвалення, залежність від групи. 18,4\% студентів як пріоритетну визначають спрямованість на себе, у навчальній діяльності вони зорієнтовані тільки на оцінки, у поведінці - проявляють агресивність, прагнуть до домінування в групі, схильні до конкуренції, тривожні.

Мотивація досягнення також є важливим показником у професійній мотивації. Від міри вираження мотивації на успіх залежить рівень упевненості студентів у власних силах, віра в можливість досягти навчальних і професійних успіхів. Зневіра у власних силах зумовлює особистісну пасивність, зниження навчальнопізнавальної активності. Аналіз результатів за методикою А. Мехрабіана вказує на домінування мотивації на уникнення невдач (у 63,8\% студентів). Таким чином, наявність прагнення до самореалізації, професійної спрямованості, виявлені в першокурсників за допомогою попередніх методик, комбінуються з домінування мотивації уникнення невдач. У навчальній діяльності під час виконання відповідальних, проблемних завдань першокурсники шукають причини відмовитися від них, невпевнені, бояться критики, результативність їхньої діяль- 
ності значно погіршується, що підтверджується даними академічної неуспішності. Такі результати можна пояснити тим, що на першому курсі студенти опановують зміст нових навчальних дисциплін, оволодівають відмінними від засвоєних раніше під час навчання у загальноосвітньому навчальному закладі способами отримання і презентації знань. Складні завдання викликають у здобувачів вищої освіти негативні емоційні переживання. Ми можемо припустити, що такі результати спричинені невідповідністю особистих здібностей, потенцій обраному фаху, вибором педагогічного вищого навчального закладу по остаточному принципу, ілюзорним уявленням студентів про легкість засвоєння навчальної програми обраної спеціальності. Тому у першокурсників не виражене прагнення оволодіти професійними знаннями, сформувати професійно важливі якості і, як наслідок, мотивація на успіх не висока.

У результаті статистичної обробки даних були виявлені статистично значущі обернені кореляційні зв'язки між базовим чинником «рівень тривожності» і «мотивація досягнення» $\left(\mathrm{r}_{\mathrm{xy}}=-0,404\right.$, при $\left.\mathrm{p} \geq 0,01\right)$. Отже, постійне переживання емоційного дискомфорту, почуття сором'язливості, скутості, незадоволеність власним актуальним станом, життєвою ситуацією призводить до зниження або взагалі відсутності бажання досягати успіху, самоствердження, самореалізації, зникає задоволеність від навчання, знижується професійна мотивація.

У студентів із вираженим показником «внутрішня конфліктність» встановлено зниження професійних мотивів $\left(\mathrm{r}_{\mathrm{xy}}=-0,332\right.$, при $\mathrm{p} \geq 0,05)$ і мотивів досягнення успіху $\left(\mathrm{r}_{\mathrm{xy}}=\right.$ $0,298$, при $\mathrm{p} \geq 0,05)$. Тобто, якщо в студентів переважає негативний фон самоставлення, який проявляється у постійній неузгодженості між «Я реальним» і «Я ідеальним», між рівнем домагань і фактичними здобутками, знижується мотивація досягати професійні цілі, у навчальній діяльності з'являються проблеми, підвищується неуспішність. Водночас ми можемо припустити, що хоч рівень мотивації до професійної діяльності в більшості характеризується як позитивний, але іï вибір був здійснений, швидше, несвідомо. Студентів привабила зовнішня сторона професії, усвідомлення чого призводить до виникнення негативних особистісних переживань і зниження мотивації досягнень.

У студентів із вираженим показником «самозвинувачення» відбувається зниження показника «професійні мотиви» $\left(\mathrm{r}_{\mathrm{xy}}=-0,336\right.$, при $\mathrm{p} \geq 0,05)$, що засвідчує той факт, що в проблемних ситуаціях, випадку невдач у навчальній діяльності, конфліктів у сфері спілкування 3 одногрупниками, викладачами студенти схильні звинувачувати самих себе, що призводить до збільшення емоційної напруги і зменшення бажання оволодівати майбутньою професією, навчатися у вищому навчальному закладі.

Висновки 3 даного дослідження. Про- 
фесійна мотивація - це складне, багатогранне явище, яке у подальшому визначає життєвий шлях людини і виступає в ролі внутрішнього фактору, який сприяє розвитку професіоналізму особистості. Вибір і прийняття професії завжди критичний момент у розвитку особистості, невміння робити свідомий вибір або ухиляння від вибору може призвести до погіршення її психоемоційного стану, появи негативних переживань, які можуть перерости у внутрішньоособистісні конфлікти.

Результати емпіричного дослідження довели, що якщо показник «внутрішня конфліктність» має тенденцію до збільшення, то рівень професійної мотивації і мотивів досягання успіхів знижуються. Високі показники рівня тривожності студентів співвідносяться із низькими показниками мотивації досягнення, що призводить до небажання досягати успіху у навчанні й у професійному розвитку. Проблемні ситуації у навчанні, у спілкуванні з одногрупниками призводять до збільшення емоційної напруги, до самозвинувачення, що також перешкоджає розвитку професійної мотивації.

Отже, професійна мотивація виступає однією із умов формування емоційної стабільності, психологічного благополуччя особистості, а їі розвиток може попередити розгортання внутрішньоособистісних конфліктів у студентів першого курсу.

\section{Перспективи подальших розвідок у} даному напрямі. Отримані дані не вичерпу- ють усіх аспектів досліджуваної проблеми. Перспективу подальших досліджень вбачаємо у визначенні умов профілактики внутрішньоособистісних конфліктів студентів першого року навчання, що зумовлені невдалим або аморфним професійним самовизначенням, розробленні корекційних програм психологічного супроводу таких студентів.

\section{Перелік використаних джерел:}

1. Барчі Б. В. Вивчення мотивів вибору професії у психологічних дослідженнях / Б.В. Барчі // Збірник наукових праць КПНУ імені Івана Огієнка, Інститут психології ім. Г.С. Костюка НАПН України. - К., 2011. - Випуск 12. - Проблеми сучасної психології. - С. 60-72.

2. Долинська Л. В. Підвищення соціально-психологічної компетентності вчителя в процесі його професійної підготовки // Нові педагогічні технології з проблем гуманізації та демократизацій навчально-виховного процесу в освітніх закладах: Матеріали міжнародної науково-практичної конференції. - Черкаси, 1998. - С. 147 149.

3. Срохін С. А. Концепція професійної мотивації студентів як фактору конкурентності на ринку праці / С.А. Єрохін, Ю.В. Нікітін, І.В. Нікітін // Проблеми вищої юридичної освіти. - 2001 - №1 (1). - С. 20-27.

4. Занюк С. Психологія мотивації / С. Занюк. - К. : Ельга, 2001. $-351 \mathrm{c}$.

5. Кусакина С. Н. Мотивация поступления в вуз у старшеклассников и студентов / С.Н. Кусакина // Психологическая наука и образование. - 2008. - №1. - С. 58-67.

6. Ложкін Г. В. Психологія конфлікту: теорія і сучасна практика: Навч. посіб./ Г.В. Ложкін, Н.І. Пов'якель. К.: ВД «Професіонал», 2007. $-416 \mathrm{c}$.

7. Маланьїна Т. М. Проблема емпіричного дослідження внутрішньоособистісних конфліктів

Т. М. Маланьїна // Гуманітарний вісник ДВН3 
«Переяслав-Хмельницький державний педагогічний університет імені Григорія Сковороди» - Додаток 4 до Вип. 31: Тематичний випуск «Проблеми емпіричних досліджень у психології» / за ред. І.П. Маноха - К.: Гнозис, 2014. - С. 64-71.

8. Поваренков Ю. П. Психологическое содержание профессионального становления человека / Ю.П. Поваренков. - М.: Изд-во УРАО, 2002. - 160 с.

9. Спиридонова Н. Ю. Связь направленности личности с выбором профессии в юношеском возрасте: автореф. дис. ... канд. психол. наук : спец. 19.00.13 «Психология развития, акмеология» / Н. Ю. Спиридонова. - М., 2011. $-23 \mathrm{c}$.

10. Паламарчук О. М. Психологічні аспекти розвитку особистісного потенціалу майбутнього фахівця у контексті інтеграції до європейського освітнього простору / О. М. Паламарчук // Гуманітарний вісник ДВНЗ «Переяслав-Хмельницький державний педагогічний університет імені Григорія Сковороди» / за ред. І. П. Маноха. - К.: Гнозис, 2016. - Т. 8, вип. 36. - С. 239-250.

11. Ames C. Classrooms: Goals, Structures, and Student Motivation // Journal of Educational Psychology. - 1992. Vol. 84. - №3. - P. 261-271.

12. Archer J. Achievement Goals as a Measure of Motivation in University Students // Contemporary Educatiunal Psychology. - 1994. - Vol. 19. - №4. - P.430446.

13. Elliot A. J. Approach and Avoidance Motivation and Achievement Goals // Educational Psychology . - 1999. Vol. 34. - №3. - P. 169-186.

14. Kaplan A., Maehr M.L. The Contributions and Prospects of Goal Orientation Theory // Educational Psychology Review. - 2007. - Vol. 19. - №2. - P. 141-184.

\section{References (Transliteration):}

1. Barchi B. V. Vivchennya motivIv viboru profesiyi $\mathrm{u}$ psihologichnih doslidzhennyah / B.V. BarchI // Zbirnik naukovih prats KPNU Imeni Ivana OgIEnka, Institut psihologIYi Im. G.S. Kostyuka NAPN UkraYini. - K.,
2011. - Vipusk 12. - Problemi suchasnoYi psihologIYi. S. $60-72$.

2. Dolinska L. V. PIdvischennya sotsIalno-psihologIchnoYi kompetentnostI vchitelya $\mathrm{v}$ protsesI yogo profesIynoYi pIdgotovki // NovI pedagogIchnI tehnologIYi z problem gumanIzatsIYi ta demokratizatsIy navchalno-vihovnogo protsesu v osvItnIh zakladah: MaterIali mIzhnarodnoYi naukovo-praktichnoYi konferentsIYi. - Cherkasi, 1998. S. 147-149.

3. ErohIn S. A. KontseptsIya profesIynoYi motivatsIYi studentIv yak faktoru konkurentnostI na rinku pratsI / S.A. ErohIn, Yu.V. NIkItIn, I.V. NIkItIn // Problemi vischoYi yuridichnoYi osvIti. - 2001 \#1 (1). - S. 20-27.

4. Zanyuk S. PsihologIya motivatsIYi / S. Zanyuk. - K. : Elga, 2001. - $351 \mathrm{~s}$.

5. Kusakina S. N. Motivatsiya postupleniya v vuz u starsheklassnikov i studentov / S.N. Kusakina // Psihologicheskaya nauka i obrazovanie. - 2008. \#1. - S. 58 $-67$.

6. Lozhkin G. V. PsihologIya konflIktu: teorIya I suchasna praktika: Navch. posIb./ G.V. LozhkIn, N.I. Pov’yakel. K.: VD «ProfesIonal», 2007. - 416 s.

7. Malanyina T. M. Problema empIrichnogo doslIdzhennya vnutrIshnoosobistIsnih konflIktIv / T. M. MalanYina // GumanItarniy vIsnik DVNZ «Pereyaslav-Hmelnitskiy derzhavniy pedagogIchniy unIversitet ImenI GrigorIya Skovorodi»-Dodatok 4 do Vip. 31: Tematichniy vipusk «Problemi empIrichnih doslIdzhen u psihologIYi» / za red. I. P. Manoha. - K. : Gnozis, 2014. - S. 64-71.

8. Povarenkov Yu. P. Psihologicheskoe soderzhanie professionalnogo stanovleniya cheloveka / Yu.P. Povarenkov. M.: Izd-vo URAO, 2002. $160 \mathrm{~s}$.

9. Spiridonova N. Yu. Svyaz napravlennosti lichnosti s vyiborom professii v yunosheskom vozraste: avtoref. Dis... kand. psihol. nauk : spets. 19.00.13 «Psihologiya razvitiya, akmeologiya» / N. Yu. Spiridonova. M., 2011. - 23 s.

10. Palamarchuk O. M. PsihologIchnI aspekti rozvitku osobistIsnogo potentsIalu maybutnogo fahIvtsya $u$ kontekstI IntegratsIYi do Evropeyskogo osvItnogo prostoru / O. M. Palamarchuk // GumanItarniy vIsnik 
DVNZ «Pereyaslav-Hmelnitskiy derzhavniy pedagogIchniy unIversitet ImenI GrigorIya Skovorodi»/ za red. I. P. Manoha. - K.: Gnozis, 2016. - T. 8, vip. 36. - S. 239-250.

11. Ames C. Classrooms: Goals, Structures, and Student Motivation // Journal of Educational Psychology. - 1992. Vol. 84. - \#3. - P. 261-271.

12. Archer J. Achievement Goals as a Measure of Motivation in University Students // Contemporary Educatiunal Psychology. - 1994. - Vol. 19. - \#4. - P.430446.

13. Elliot A.J. Approach and Avoidance Motivation and Achievement Goals // Educational Psychology . - 1999. Vol. 34. - \#3. - P. 169-186.

14. Kaplan A., Maehr M.L. The Contributions and Prospects of Goal Orientation Theory // Educational Psychology Review. - 2007. - Vol. 19. -\#2. - P. 141-184.

\section{Shulga Galyna}

Candidate of pedagogical sciences, docent of the chair of psychology and social work of Mykhaylo Kotsybynskiy Vinnytsia State Pedagogical University, Vinnytsia (Ukraine)

\section{Kolomiiets Lesia}

Candidate of pedagogical sciences, senior lecturer of the chair of psychology and social work of Mykhaylo Kotsybynskiy Vinnytsia State Pedagogical University, Vinnytsia (Ukraine)

\section{THE INFLUENCE OF PROFESSIONAL MOTIVATION ON OCCURRENCE OF INTRAPERSONAL CONFLICT AMONG STUDENTS OF THE FIRST YEAR OF STUDY}

\section{ABSTRACT}

The article is devoted to the problem of the influence of professional motivation on the emergence of intrapersonal conflict among students of the first year of studying the specialty "Preschool education". The authors describe the reasons for choosing a pedagogical profession by students of the first year in accordance with the dominant motives, they to find out the essence of professional motivation and describ the peculiarities of the motivational sphere of the students of the first year of study. The greatest attention is paid to the clarification of the role of professional motivation in the formation of a future specialist, to the its impact on the development of professionalism of the individual, on educational and cognitive motives, motives for achieving success, emotional well-being of the individual. It is noted that the process of primary professionalization often causes students to experience uncertainty in their own future, to the negative emotional states and to the intrapersonal conflicts. Diagnosis and correction of the formation of professional motifs for students of the first year of study will improve the process of their adaptation to new conditions, will facilitate the structuring of personal meanings regarding the process of acquisition of education, the inclusion in the format of a new kind of activity - educational-professional.

The article shows the results of the empirical study of the influence of professional motivation on the emergence of intrapersonal conflict of the students of the first year of study. It is established that students consider studying at a higher educational institution as a prospect of perfect mastery of a profession; It was found out that professional formation is associated with the possibilities of creative self-realization; educationalcognitive activity is not recognized as significant; 
the productivity of inclusion in educational activity depends on the time spent on independent work, the volume of mastering the educational material, the degree of self-organization, the success of overcoming obstacles; the low level of formation of the motives of students' educational activity leads to a neutral attitude to the profession, situational interest in issues of professional growth, passivity and lack of initiative, the emergence of dissatisfaction with the life situation and subjective achievements; low level of professional motivation leads to internal conflicts among students, to increase emotional stress, decrease motives to succeed in studying and in professional development.

The prospect of further scientific researches on the research problem, the definition of conditions for the prevention of intrapersonal conflicts among students of the first year of study, that determined by the failure or amorphous professional self-determination, the development of correctional programs for the psychological support of such students was determined.

Key words: motivation, professional motivation, professional development of an individual, intrapersonal conflict, motives of achievement.

\section{Шульга Галина Борисовна}

Кандидат педагогических наук, доиент кафедры психологии и социальной работь Винницкого государственного педагогического университета имени Михаила Кочююинского, г. Винница (Украина)

\section{Коломиец Леся Игоревна}

Кандидат педагогических наук, старший преподава- тель кафедры психологии и сочиальной работы Винниикого государственного педагогического университета имени Михаила Коцююбинского, г. Винниц̧а (Украина)

\section{ВЛИЯНИЕ ПРОФЕССИОНАЛЬНОЙ МОТИВАЦИИ НА ВОЗНИКНОВЕНИЕ ВНУТРИЛИЧНОСТНОГО КОНФЛИКТА У СТУДЕНТОВ ПЕРВОГО ГОДА ОБУЧЕНИЯ}

Аннотация. Статья посвящена проблеме влияния профессиональной мотивации на возникновение внутриличностного конфликта у студентов первого года обучения специальности «Дошкольное образование». Авторами охарактеризованы причины выбора педагогической профессии студентами первого курса в соответствии с доминантными мотивами, выяснена сущность профессиональной мотивации и описаны особенности мотивационной сферы студентов первого года обучения. Больше всего внимания уделено выяснению роли профессиональной мотивации в становлении будущего специалиста, ее влияние на развитие профессионализма личности, на учебно-познавательные мотивы, мотивы достижения успеха, эмоциональное благополучие личности. Отмечено, что процесс первичной профессионализации нередко вызывает у студентов появление неуверенности в собственном будущем, негативных эмоциональных состояний и внутриличностных конфликтов. Диагностика и коррекция сформированности профессиональных мотивов у студентов первого года обучения позволит улучшить процесс их адаптации к новым условиям, бу- 
дет способствовать структурированию личностных смыслов о процессе получения образования, включению в формат нового вида деятельности - учебно-профессиональной.

В статье представлены результаты эмпирического исследования влияния профессиональной мотивации на возникновение внутриличностного конфликта у студентов первого года обучения. Установлено, что студенты рассматривают обучение в высшем учебном заведении как перспективу совершенного овладения профессией; выяснено, что профессиональное становление связывается с возможностями творческой самореализации; учебно-познавательная деятельность не признается значимой; продуктивность включения в учебную деятельность зависит от затрат времени на самостоятельную работу, объема освоения учебного материала, степени самоорганизации, успешности преодоления препятствий; низкий уровень сформированности мотивов учебной деятельности студентов приводит к нейтральному отношение к профессии, ситуативной заинтересованности вопросами профессионального роста, пассивности и безынициативности, возникновение неудовлетворенностью жизненной ситуацией и субъективными достижениями; низкий уровень профессиональной мотивации приводит к возникновению у студентов внутренней конфликтности, к увеличению эмоционального напряжения, снижение мотивов достигать успеха в учебе и в профессиональном развитии.
Определена перспектива дальнейших научных поисков по проблеме исследования, а именно определение условий профилактики внутриличностных конфликтов студентов первого года обучения, которые обусловленные неудачным или аморфным профессиональным самоопределением, разработка коррекционных программ психологического сопровождения таких студентов.

Ключевые слова: мотивация, профессиональная мотивация, профессиональное развитие личности, внутриличностный конфликт, мотивы достижения.
Дата отримання статті: 28.11.2017

Дата рекомендації до друку: 21.12.2017 